\title{
Overproduction and characterization of a recombinant D-amino acid oxidase from Arthrobacter protophormiae
}

\author{
Birgit Geueke • Andrea Weckbecker • Werner Hummel
}

Received: 12 October 2006 /Revised: 17 November 2006 / Accepted: 17 November 2006 / Published online: 6 February 2007

(C) Springer-Verlag 2007

\begin{abstract}
A screening of soil samples for D-amino acid oxidase (D-AAO) activity led to the isolation and identification of the gram-positive bacterium Arthrobacter protophormiae. After purification of the wild-type D-AAO, the gene sequence was determined and designated dao. An alignment of the deduced primary structure with eukaryotic D-AAOs and D-aspartate oxidases showed that the D-AAO from A. protophormiae contains five of six conserved regions; the $\mathrm{C}$-terminal type 1 peroxisomal targeting signal that is typical for D-AAOs from eukaryotic origin is missing. The dao gene was cloned and expressed in Escherichia coli. The purified recombinant D-AAO had a specific activity of $180 \mathrm{U} \mathrm{mg}$ protein $^{-1}$ for D-methionine and was slightly inhibited in the presence of L-methionine. Mainly, basic and hydrophobic D-amino acids were oxidized by the strictly enantioselective enzyme. After a high cell density fermentation, $2.29 \times 10^{6} \mathrm{U}$ of D-AAO were obtained from 151 of fermentation broth.
\end{abstract}

\section{Introduction}

D-Amino acid oxidases (D-AAOs, EC 1.4.3.3) constitute a well-investigated group of flavoenzymes that are known since Krebs 1935. They catalyze the oxidative deamination

B. Geueke · A. Weckbecker $\cdot$ W. Hummel

Institute of Molecular Enzyme Technology,

Heinrich Heine University Düsseldorf, Research Centre Jülich,

52426 Jülich, Germany

\section{Present address:}

B. Geueke $(\bowtie)$

Swiss Federal Institute of Aquatic Science (Eawag),

Ueberlandstrasse 133,

8600 Dübendorf, Switzerland

e-mail: birgit.geueke@eawag.ch of D-amino acids to the corresponding keto acids, produce ammonia and hydrogen peroxide as by-products and contain flavin adenine dinucleotide (FAD) as non-covalently bound cofactor. D-AAOs from fungi, fish, birds, reptiles and different mammalian tissues have been discovered during the last decades (Konno and Yasumura 1992). The best explored D-AAOs originate from pig kidney (Curti et al. 1973; Fukui et al. 1987; Watanabe et al. 1989) and the yeasts Rhodotorula gracilis (Alonso et al. 1998; Casalin et al. 1991; Harris et al. 1999; Molla et al. 1998; Pilone et al. 1989a; Pilone et al. 1987; Ramon et al. 1998) and Trigonopsis variabilis (Berg and Rodden 1976; Gonzalez et al. 1997; Isoai et al. 2002; Szwajcer and Mosbach 1985; Yu et al. 2002). The crystal structures of the D-AAOs from R. gracilis and pig kidney were resolved (Mattevi et al. 1996; Miura et al. 1997; Umhau et al. 2000), and different approaches of enzyme engineering were performed to better understand their catalytic, structural and biotechnological properties (Boselli et al. 2004; Caldinelli et al. 2006; Ju et al. 2000; Piubelli et al. 2002; Sacchi et al. 2002).

Most of the characterized D-AAOs oxidize hydrophobic, neutral and basic D-amino acids, whereas D-glutamic acid and D-aspartic acid are not accepted as substrates. These substances were oxidized by a functional related group of enzymes, the D-aspartate oxidases (D-AspO, EC 1.4.3.1), that oxidize solely acidic D-amino acids (Negri et al. 1987; Simonic et al. 1997). D-AAOs from yeasts are involved in the metabolic utilization of D-amino acids, whereas the physiological function of mammalian D-AAOs is still uncertain. Recently, it was demonstrated that D-AAO regulates the $\mathrm{N}$ methyl-D-aspartate receptor-mediated neurotransmission in the brain by degrading D-serine (Mothet et al. 2000).

D-AAOs are of special biotechnological interest, as some enzymes of this group catalyze the first step in large-scale processes that lead to 7-amino cephalosporanic acid, a 
precursor of semisynthetic cephalosporins (Pilone and Pollegioni 2002; Pollegioni et al. 2004; Tishkov and Khoronenkova 2005). In combination with hydride reducing agents, D-AAOs were also applied for the cyclic deracemization and stereoinversion of $\alpha$-amino acids (Beard and Turner 2002).

Basic local alignment search tool (BLAST) searches reveal various sequences from bacteria that show similarities to known eukaryotic D-AAOs, but no functional bacterial D-AAO has been described so far. In this paper, we report on the purification, overexpression and biochemical characterization of a highly active D-AAO from the environmental isolate Arthrobacter protophormiae.

\section{Materials and methods}

Media and growth conditions

Different dilutions of soil suspensions were prepared in $0.9 \%$ $\mathrm{NaCl}$ solution and plated on mineral agar medium containing $0.2 \mathrm{~g} \mathrm{l}^{-1}$ of sodium propionate as sole carbon source and $0.01 \mathrm{~g}^{-1}$ of potassium nitrate as sole nitrogen source (Goodfellow and Minnikin 1981). Strains were isolated by transferring colonies to M65 medium (10 g of malt extract, $4 \mathrm{~g}$ of glucose and $4 \mathrm{~g}$ of yeast extract per liter) that was solidified by the addition of $1.5 \%(\mathrm{w} / \mathrm{v})$ agar. Single colonies were subsequently inoculated in M65 broth and grown at $30^{\circ} \mathrm{C}$. The crude extracts of the cells and the culture supernatants were separately tested for D-AAO activity.

One soil isolate that exhibited D-AAO activity was assigned to the species A. protophormiae by the Deutsche Sammlung von Mikroorganismen und Zellkulturen (DSM 15035). The strain was grown aerobically in M65 broth supplemented with $2.7 \mathrm{~g}$ of L-alanine per liter $(\mathrm{pH} 7.2)$. After $24-28 \mathrm{~h}$ of cultivation at $30^{\circ} \mathrm{C}$, the cells were harvested by centrifugation and stored at $-20^{\circ} \mathrm{C}$.

Purification of D-AAO from A. protophormiae and Escherichia coli BL21(DE3) carrying pE1D

Fifty grams of $A$. protophormiae cells were suspended in $10 \mathrm{mM}$ potassium phosphate buffer $(\mathrm{pH}$ 7.0) and disrupted in a glass bead mill (SCP-Disintegrator, Innomed-Konsult AG, Sweden) as described previously (Geueke and Hummel 2002). The crude extract was loaded onto a Q-Sepharose FF column (2.6 by $10 \mathrm{~cm}$; GE Healthcare) that was equilibrated with $10 \mathrm{mM}$ potassium phosphate buffer ( $\mathrm{pH} 7.0$ ). The flow rate was $2 \mathrm{ml} \mathrm{min}^{-1}$. The column was washed with $10 \mathrm{mM}$ potassium phosphate buffer ( $\mathrm{pH}$ 7.0) containing $0.2 \mathrm{M} \mathrm{NaCl}$ and the D-AAO eluted at a concentration of $0.35 \mathrm{M}$ sodium chloride. Active fractions were pooled and loaded onto a column that was packed with ceramic MacroPrep hydroxyapatite, type I (1.6 by $8.3 \mathrm{~cm}$; BioRad). The column was equilibrated with $150 \mathrm{mM} \mathrm{KCl}$ in $10 \mathrm{mM}$ potassium phosphate buffer (pH 6.8) and operated at a flow rate of $2 \mathrm{ml} \mathrm{min}^{-1}$. The D-AAO activity was detected in the flow through. The active fractions were dialyzed against $50 \mathrm{mM}$ triethanolamine (TEA)-HCl buffer containing 20\% PEG 20000 (PEG, polyethylene glycol; $\mathrm{pH}$ 7.0). The concentrated sample was loaded onto a preparative, native polyacrylamide gel (10\%) using the 491 Prep Cell (BioRad) and eluted with $50 \mathrm{mM}$ TEA-HCl buffer (pH 7.0).

Escherichia coli BL21(DE3) carrying the plasmid pE1D was cultivated aerobically in $100-\mathrm{ml}$ shaking flasks containing 20-ml Luria-Bertani (LB) medium supplemented with $100 \mu \mathrm{g}$ ampicillin $\mathrm{ml}^{-1}$. The cells were incubated at $37^{\circ} \mathrm{C}$ and $200 \mathrm{rpm}$ and induced with $0.1 \mathrm{mM}$ isopropyl$\beta$-D-thiogalactopyranoside (IPTG) at an optical density of $\mathrm{OD}_{550}$ 0.5. After induction, the temperature was reduced to $30^{\circ} \mathrm{C}$. Escherichia coli BL21(DE3) carrying pE1D was disrupted by ultrasonification. The recombinant D-AAO was purified using anion exchange and hydroxyapatite chromatography as described for the wild-type enzyme.

\section{$\mathrm{N}$-terminal sequencing}

The N-terminal sequence of the D-AAO was determined on an Automated Sequencer 477A with a 12A PTH analyser (Applied Biosystems). Partially purified D-AAO was separated by sodium dodecyl sulfate-polyacrylamide gel electrophoresis (SDS-PAGE) and digested with the endoproteinase Lys-C. The digest, separation by high-performance liquid chromatography (HPLC) and sequencing of one internal peptide was carried out by Toplab (Martinsried, Germany).

\section{PCR conditions}

All PCR reactions were performed using the Taq polymerase (Qiagen) with the supplied buffer. Two degenerated primers were constructed for the partial amplification of the dao gene from genomic DNA (P8for 5'-cgsatcaccgtsatcggctccggcgtsat$3^{\prime}$ and P10rev 5'-cttgtgytgsagsacytcsaggecytcsag-3'). The amplification procedure consisted of $3 \mathrm{~min}$ at $95^{\circ} \mathrm{C}$ followed by 8 cycles of $40 \mathrm{~s}$ at $95^{\circ} \mathrm{C}, 1 \mathrm{~min}$ at $72-64^{\circ} \mathrm{C}, 1 \mathrm{~min}$ at $72^{\circ} \mathrm{C}$ and 25 cycles of $40 \mathrm{~s}$ at $95^{\circ} \mathrm{C}, 1 \mathrm{~min}$ at $68^{\circ} \mathrm{C}$ and $1 \mathrm{~min}$ at $72^{\circ} \mathrm{C}$. The reaction was stopped after a final incubation step for $10 \mathrm{~min}$ at $72^{\circ} \mathrm{C}$. DNA sequencing was carried out by Sequiserve (Vaterstetten, Germany).

Identification and cloning of the dao gene

The dao gene sequence was isolated with the Universal GenomeWalker ${ }^{\mathrm{TM}}$ Kit (BD Clontech; http://www.clontech. com/products/literature/pdf/brochures/GenomeWalker.pdf). 
A. protophormice, D-A AO M. lepres S. coelicolar

A. gambiae

C. elegans

H. sopiens, D-A spO

B. taures, D-AspO

A. protophormiae, D-AAO M. leproe

S. coelicolor

A. gambiae

C. elegans

H. sopiens, D-A spO

B. taures, O-AspO

A. protophormice, D-A AO M. lepree

S. coelicolor

A. gambiae

C. elegans

$H$. sapiens, D-A spO

B. tourus, D-AspO

A. protophormiae, D-A AO M. Leproe

S. coelicolor

A. gambiae

C. elegans

H. sapiens, D-A spO

B. tourys, O-AspO

A. protopharmiae, D-A AO M. lepree

S. coelicalor

A. gambioe

C. elegans

H. sapiens, D-A spO

B. tourus, D-AspO

A. protophomiae, D-A AO M. lepras

S. coelicolar

A. gambiae

C. elegans

H. sopiens, D-A spO

B. tourus, O-AspO

A. protophormiae, D.A AO M. Ieprae

S. coelicaior

A. gambioe

C. elegans

H. sapiens, D-A spO

B. tourus, D-AspO

A. protophormiae, D-A AO

M. leprae

S. coelicolor

A. gambiae

C. elegans

H. sapiens, D-AspO

B. taurys, O-AspO

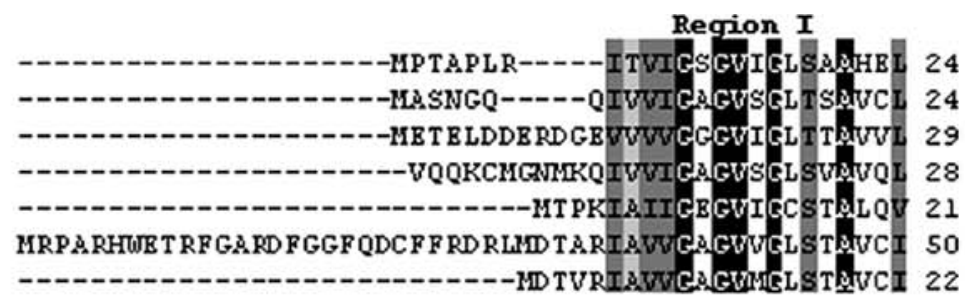

AMAGHQVT---VAYDQELAECVSSVAASTWF PYHSEN--SPA.ADLLADS 69 AEAGWPVQ---LWAAMMPQQT TSAVAGAWWAP PRPEBR-ASTSLAWTGHS 70 ABRGRRUR---LWT REPAERT TSVVAGGLWWPYRIEP--VALAOAWALRS 74 A BHYYNVANVT L ISENUSPNTT GD GSAGLWGPYYCGNT PDHKTVKWSSBT 78 AQAVPDAR-VTVLSDRPFEQTCSFGPAGLFRIDDIAN------REFGKST 64 SKLVPRCS-VTIISDKFT PDT TSDVAAGML I PHTYPDT P IHTQKQWFRET 99 SKIVPGCS-ITUISDKFT PET TSDVA.AGLL I P PTYPDTPIQKQKQWFKET 71

LARFBQLSBHP---BTETDLRRGLNVDHLPG--ADRS--WTRIVAGTBBA 112 LQIFRE LAND P---ST GURMA PAL TVGD LPG--ANAMGLASKLIPDLRPA 115 LDVYBELAARPG--QTCVRMLEG-VLGBTGL--DEVDGWASARLPGLRSA 119 HT F FHQLWKNGLGCKI CUCLQPCMRLT TDPN--GYPBPAWKEIVFGCQKI 126 FDWF AHIHRT BKGDKT GVKLLSGHIQSD SKBRL BQQQKAY GD IVYNF RFL 114 FNHL FAISNSABACDAGUHLVSGWOIFQSTP--TBEVPFWADUVLGRKM 147 FDHLFAIUNSABA EDACUILVSGWQIFQSIP--TBEVPYWADUVLGRRKA 119 SPADLPDGA------HAGVWATVPIITMSTYLGE LRGRVBRLCADFAKG 155 DLADLPDGF------GAGF FGTMPMIDIPOYLD IT TARLAABCCBLBTR 158 SA.AYAG-------TGLWARL PLIDMSTHLPWLRERLLASGGTVBD R 159 QBPBLKRLSNBHGRSYTGGYHFAT FTCEPSGLLPYLFNRFIAUGGKFVAS 176 BKREILDLF PN---PSBHCIHYTAFASBGNKY P LKFOCQAFGVBFLHR 161 TBABLKKKP P-----QYVF GQAFT TLKCBCPAYLPKLEKRIKGSCGWTLTR 192 TKD BLKKR P-----QHVF GHAFT T LKC BGPAYLPLLOKRVKGNGGLILTR 164

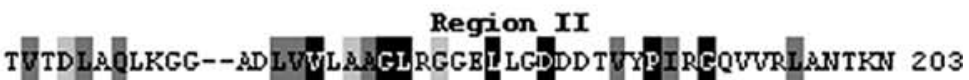

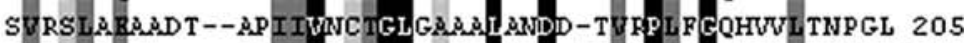
AVTDLARAD----APWUNCIGLGARELVPD-PAVEPURCOLVWBNPGI 204 KURNRD BIILNRPUDLIUNCSGLGSL BLASDRA-VLPIRCOVARVSA.PWI 225 KWRD B BLANBG-YDVIVNC AGLSGGTLAGDDSWYPIREVUDVBAHWH 210 RIED LWBLHPS--FD IVUNCSEL GSROLAGD SK-I FPUREQVLOVQAPTV 239 RIEDLWRLHPS--FDIVUNCSGLGSROLAGDSK-IFPVRCOVLKUOA.PWV 211

Region III
LTQWLCDDNYPDGUSYIIPRRED IIVGGTD TANDWNREVEPQTSIDILER 253 QQLFLEUNNGS-BUICY PHPLRUVCGGISIPGRWDT T PDPAVTDRILQR 254 HNOLVA.ADADSGETTYFL PQPGRL LLGGTABEDAWST EPDPEVASAIVRR 254 YBVILD---DSDDGNYII PNCBTVILGGTHOMND FNRNVKRDDSRF I FDG 272 KHFN-----YKD FIT FT I PKENSVUI GSVKQBNRWDL BI TDVDRKD IL BR 255 EHFIR----DGSGLTYIYPGTSHUTLEGTROKGDWINLSPDAENSREILSR 285 KHFIR----DSSGLTYIYDGUSNUTLGTRQKGDWNLSPDABISKBILSR 257
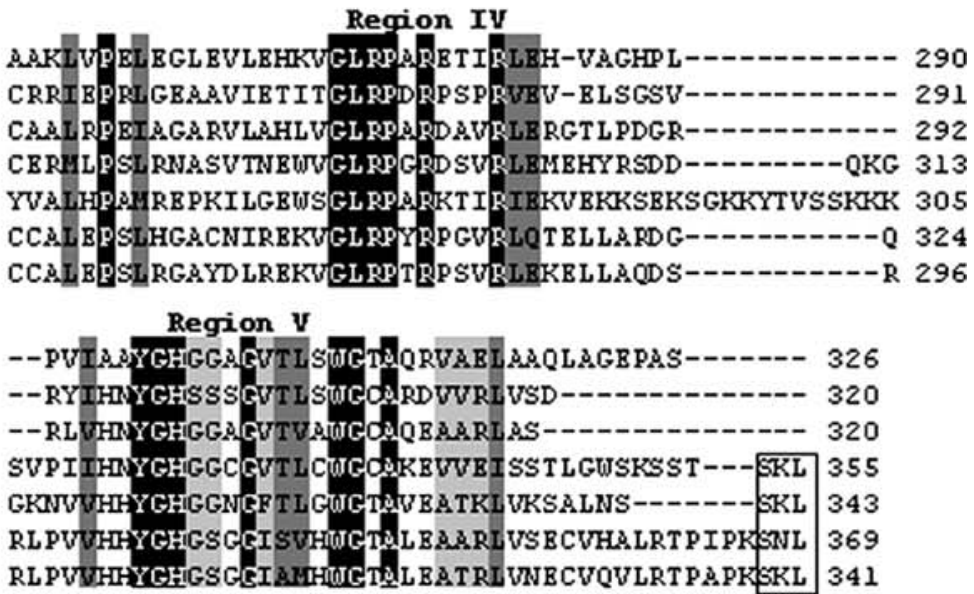
Genomic DNA was cut with NruI, EcoRV, PvuII, StuI, NaeI and FspI (BD Clontech or New England Biolabs). The GenomeWalker adaptors were ligated to the genomic DNA fragments, and these libraries were used as templates in nested PCR reactions with the following primers: Apfor3 5'-gcaccaggtcaccgtcgectacgacca-3', Aprev3 5'-caccagcttgg cagcgcgttccagga-3', Apfor4 5'-cgccgccgccatctggttcceg tacca-3', Aprev4 5'-ctgcggttcgacttcgcggttccagtcgtt-3'. The amplification procedures consisted of $3 \mathrm{~min}$ at $94^{\circ} \mathrm{C}$ followed by 4 cycles of $1 \mathrm{~min}$ at $94^{\circ} \mathrm{C}, 30 \mathrm{~s}$ at $65^{\circ} \mathrm{C}$, $3 \mathrm{~min}$ at $72^{\circ} \mathrm{C}, 30$ cycles of $1 \mathrm{~min}$ at $94^{\circ} \mathrm{C}, 30 \mathrm{~s}$ at $62^{\circ} \mathrm{C}$ and $3 \mathrm{~min}$ at $72^{\circ} \mathrm{C}$. The reaction was stopped after a final incubation step for $10 \mathrm{~min}$ at $72^{\circ} \mathrm{C}$.

The restriction sites NdeI and BamHI were attached to the dao gene by PCR to allow cloning into the expression plasmid pET21a (EMD Biosciences). Genomic DNA from A. protophormiae was used as a template, and the following primers were applied: ApNdeIfor 5'-ggaattccatatgcccacag caccgttgag-3' and ApBamHIrev 5'-cgggatccc tagctggecggetcgeca- 3 '. The PCR product and pET21a were digested with NdeI and BamHI, purified, ligated and transformed into E. coli BL21(DE3). Clones were tested by restriction digest and sequencing of the newly obtained plasmid $\mathrm{pE} 1 \mathrm{D}$.

High cell density fermentation of E. coli BL21(DE3) carrying $\mathrm{pE} 1 \mathrm{D}$

A fed-batch fermentation was carried out using the following medium for the batch (per liter): $0.2 \mathrm{~g}$ of $\mathrm{NH}_{4} \mathrm{Cl}$, $2 \mathrm{~g}$ of $\left(\mathrm{NH}_{4}\right)_{2} \mathrm{SO}_{4}, 13 \mathrm{~g}$ of $\mathrm{KH}_{2} \mathrm{PO}_{4}, 10 \mathrm{~g}$ of $\mathrm{K}_{2} \mathrm{HPO}_{4}, 6 \mathrm{~g}$ of $\mathrm{NaH}_{2} \mathrm{PO}_{4} \cdot \mathrm{H}_{2} \mathrm{O}, 3 \mathrm{~g}$ of yeast extract, $2 \mathrm{~g}$ of glucose, $0.1 \mathrm{~g}$ of ampicillin, $9.3 \mathrm{mg}$ of $\mathrm{Na}_{2}$ EDTA $2 \mathrm{H}_{2} \mathrm{O}, 0.1 \mathrm{~g}$ of thiamine, $0.3 \mathrm{ml}$ of antifoam, $5 \mathrm{ml}$ of vitamin and $4 \mathrm{ml}$ of trace element solution. The feed medium consisted of $0.2 \mathrm{~g}$ of $\mathrm{NH}_{4} \mathrm{Cl}, 2 \mathrm{~g}$ of $\left(\mathrm{NH}_{4}\right)_{2} \mathrm{SO}_{4}, 13 \mathrm{~g}$ of $\mathrm{KH}_{2} \mathrm{PO}_{4}, 10 \mathrm{~g}$ of $\mathrm{K}_{2} \mathrm{HPO}_{4}, 6 \mathrm{~g}$ of $\mathrm{NaH}_{2} \mathrm{PO}_{4}, 21 \mathrm{~g}$ of yeast extract, $600 \mathrm{~g}$ of glucose, $10 \mathrm{~g}$ of $\mathrm{MgSO}_{4} \cdot 7 \mathrm{H}_{2} \mathrm{O}, 0.4 \mathrm{ml}$ of antifoam, $5 \mathrm{ml}$ of vitamin and $2 \mathrm{ml}$ of trace element solution per liter. The vitamin solution contained (per liter): $0.1 \mathrm{~g}$ of riboflavin, $10 \mathrm{~g}$ of thiamine $/ \mathrm{HCl}, 0.5 \mathrm{~g}$ of nicotinic acid, $0.5 \mathrm{~g}$ of

4 Fig. 1 Alignment of D-AAO from A. protophormiae (AAP70489), four hypothetical D-AspOs and two mammalian D-AspO. The sequence identities of the D-AAO from A. protophormiae to the putative DAspOs as well as the mammalian D-AspOs and the corresponding accession numbers are as follows: 33\%-Mycobacterium leprae (CAC30966), 37\% - Streptomyces coelicolor (T35265), 35\%-Anopheles gambiae (EAA01013), 32\% - Caenorhabditis elegans (T19979), 29\% - human D-AspO (AAH32786), 31\% - bovine D-AspO (P31228). The alignment was generated with the ClustalW algorithm. Identical amino acids are marked black, residues with high similarity dark gray and with low similarity light gray. Regions I and III and regions II, IV and $V$ are involved in coenzyme and substrate binding, respectively. All eukaryotic proteins have the C-terminal type 1 peroxisomal targeting signal $\mathrm{S}(\mathrm{K} / \mathrm{N}) \mathrm{L}$ (marked by a frame) pyridoxine $/ \mathrm{HCl}, 0.5 \mathrm{~g}$ of Ca-panthotenate, $1 \mathrm{mg}$ of biotin, $2 \mathrm{mg}$ of folic acid and $10 \mathrm{mg}$ of cyanocobalamin. The trace element solution contained (per liter): $10 \mathrm{~g}$ of $\mathrm{CaCl}_{2} \cdot \mathrm{H}_{2} \mathrm{O}, 0.5 \mathrm{~g}$ of $\mathrm{ZnSO}_{4} \cdot 7 \mathrm{H}_{2} \mathrm{O}, 0.25 \mathrm{~g}$ of $\mathrm{CuCl}_{2} \cdot 2 \mathrm{H}_{2} \mathrm{O}$, $2.5 \mathrm{~g}$ of $\mathrm{MnSO}_{4} \cdot \mathrm{H}_{2} \mathrm{O}, 1.75 \mathrm{~g}$ of $\mathrm{CoCl}_{2} \cdot 6 \mathrm{H}_{2} \mathrm{O}, 0.125 \mathrm{~g}$ of $\mathrm{H}_{3} \mathrm{BO}_{3}, 2.5 \mathrm{~g}$ of $\mathrm{AlCl}_{3} \cdot 6 \mathrm{H}_{2} \mathrm{O}, 0.5 \mathrm{~g}$ of $\mathrm{Na}_{2} \mathrm{MoO}_{4} \cdot 2 \mathrm{H}_{2} \mathrm{O}$, $10 \mathrm{~g}$ of $\mathrm{FeSO}_{4} \cdot 7 \mathrm{H}_{2} \mathrm{O}$.

The fermenter was inoculated by adding $1 \%(\mathrm{v} / \mathrm{v})$ of preculture grown in LB medium containing $100 \mu \mathrm{g}$ of ampicillin $\mathrm{ml}^{-1}$. The cultivation was carried out in a Techfors fermenter using the IRIS software (Infors, Bottmingen, Switzerland). The batch volume was 101 and the feed volume $5 \mathrm{l}$. For the fed-batch fermentation, an exponential feeding strategy according to Korz et al. (1995) was slightly modified and applied according to the following equation:

$m_{\mathrm{S}}(t)=\left(\frac{\mu_{\mathrm{set}}}{y_{X / S}}+m\right)-V\left(t_{0}\right)-X\left(t_{0}\right)-e^{\mu_{\mathrm{set}}\left(t-t_{0}\right)}$

$m_{\mathrm{S}}$ is the mass flow of substrate $\left(\mathrm{g} \mathrm{h}^{-1}\right), y_{\mathrm{X} / \mathrm{S}}$ is the biomass/ substrate yield coefficient $\left(\mathrm{g} \mathrm{g}^{-1}\right), m$ is the specific maintenance coefficient $\left(\mathrm{g} \mathrm{g}^{-1} \mathrm{~h}^{-1}\right), X$ is the biomass concentration $\left(\mathrm{g} \mathrm{l}^{-1}\right)$ and $V$ is the cultivation volume (l). The constant specific growth rate $\mu_{\text {set }}$ was set to $0.12 \mathrm{~h}^{-1}$. The cells were induced with $0.5 \mathrm{mM}$ IPTG after $28 \mathrm{~h}$ of cultivation. The $\mathrm{pO}_{2}$ was adjusted to $30 \%$ by adapting the stirrer speed, the pressure and the aeration rate. The $\mathrm{pH}$ was maintained at 7 by adding $\mathrm{NH}_{4} \mathrm{OH}$, and the temperature was kept at $30^{\circ} \mathrm{C}$. The cells were harvested with a separator KA06 (Westfalia, Oelde, Germany) after a total fermentation time of $39 \mathrm{~h}$.

Analytical methods

The D-AAO activity was measured spectrophotometrically at $30^{\circ} \mathrm{C}$ and $436 \mathrm{~nm}$ following the oxidation of $o$ dianisidine by hydrogen peroxide that was catalyzed by an excess of peroxidase $\left(\varepsilon=8.1 \mathrm{mM}^{-1} \mathrm{~cm}^{-1}\right)$. Unless otherwise stated, $1 \mathrm{ml}$ of assay mixture contained $10 \mathrm{mM}$ D-methionine, 0.2 M TEA-HCl buffer ( $\mathrm{pH} 7.6$ ), $0.2 \mathrm{mg}$ of $o$-dianisidine, $100 \mathrm{U}$ peroxidase and D-AAO in limiting amounts. One $U$ was defined as the amount of enzyme that catalyzes the degradation of $1 \mu \mathrm{mol}$ D-amino acid per minute. The $K_{\mathrm{m}}$ for the D-AAO was determined at $30^{\circ} \mathrm{C}$ with D-methionine concentrations in the range of $0.2-$ $10 \mathrm{mM}$. The influence of L-methionine on the D-AAO activity was measured in the presence of $90 \mathrm{mM} \mathrm{L}-$ methionine and 1 to $20 \mathrm{mM}$ D-methionine. The kinetic data were fitted with the MicroMath Scientist software (Saint Louis, USA).

Protein concentration was determined according to Bradford with bovine serum albumin as a standard. The purity and expression rates of D-AAO samples were 
monitored by polyacrylamide gel electrophoresis using Bis/ Tris-gels (4-12\%) and the NuPAGE-System (Invitrogen). The native molecular weight of the purified enzyme was determined by gel filtration with a Superdex 200 PG column as published previously (Geueke and Hummel 2002). Isoelectric focussing was performed using precast Serva polyacrylamide gels with a narrow $\mathrm{pH}$ range ( $\mathrm{pH} 4-6)$.

\section{Accession number}

The nucleotide sequence of the dao gene was submitted to the GenBank under accession no. AY306197.

\section{Results}

Screening for D-AAO activity

A selective screening of 99 soil samples was performed to isolate bacteria that belong to the genera Rhodococcus and Nocardia and have L-amino acid oxidase activity (Geueke and Hummel 2002). Four of the isolated strains exhibited DAAO activity, whereas only one isolate oxidized L-amino acids. The strain with the highest activity toward the Damino acids D-phenylalanine, D-leucine and D-methionine was a gram-positive, non-motile and strict aerobic bacterium. Analysis of the 16S rDNA gene sequence showed that the organism belongs to the species A. protophormiae (DSM15035). Under the reported growth conditions, a specific activity of $0.003 \mathrm{U} \mathrm{mg}$ protein ${ }^{-1}$ was reached in the crude extract of the wild-type strain with D-methionine as substrate. Different D- and L-amino acids were added to the medium and tested as possible inducers, but no increase in the activity could be observed (data not shown). As the attempt to raise the D-AAO expression rate in the wild type to a biotechnologically interesting level did not seem to be promising, we decided to identify the dao gene.

Purification of the D-AAO and identification of the dao gene sequence

The D-AAO was purified from $50 \mathrm{~g}$ of $A$. protophormiae cells using two chromatographical steps followed by dialysis and preparative native gel electrophoresis. The enzyme was partially inactivated during the purification procedure. The $\mathrm{N}$-terminal sequence of the D-AAO was determined by automated Edman degradation (PTALPRITVIGSGVIGL SAA). The N-terminal methionine seemed to be processed. After proteolytic digestion with endoproteinase Lys-C and separation of the peptides by HPLC, one internal peptide was also sequenced (LVPELEGLEVLEHK). Degenerated primers were designed on the basis of this sequence information and used for PCR. A fragment of $700 \mathrm{bp}$ was amplified and identified as part of the dao gene. The application of the Universal GenomeWalkerTM Kit led to a DNA fragment of $1,933 \mathrm{bp}$ that was completely sequenced by primer walking. The dao open reading frame is coding for a protein of 326 amino acids corresponding to a theoretical molecular mass of $34.6 \mathrm{kDa}$ per monomer. The start codon ATG is preceded by a potential ribosome binding site (aaagga).

A BLAST search revealed that the D-AAO from $A$. protophormiae showed high similarities to hypothetical proteins from Mycobacterium leprae (CAC30966), Streptomyces coelicolor (T35265), Anopheles gambiae (EAA01013) and Caenorhabditis elegans (T19979) and to D-AspO from human (AAH32786) or bovine (P31228) origin (Fig. 1).

Heterologous expression of the dao gene

The dao gene was cloned into the multiple cloning site of the expression plasmid pET21a yielding pE1D that was subsequently transformed into E. coli BL21(DE3). Experiments in shaking flasks were performed to optimize the expression conditions by varying the induction temperature $\left(25,30,37^{\circ} \mathrm{C}\right)$, the IPTG concentration $(0.01-1 \mathrm{mM})$ and the induction time $(2-6 \mathrm{~h})$. Best results were obtained when the cells were induced with $0.1 \mathrm{mM}$ IPTG at an optical density of 0.5 followed by $4 \mathrm{~h}$ of incubation at $30^{\circ} \mathrm{C}$. Under these conditions, the maximal specific D-AAO activity in the crude extract reached $30 \mathrm{U} \mathrm{mg} \mathrm{protein}^{-1}$.

Different concentrations of FAD $(0-15 \mu \mathrm{M})$ were added to the assay mixture to measure if the enzyme was partially expressed as apoenzyme and if it could be reconstituted by the addition of cofactor. The activity in the crude extracts was not increased when external FAD was added.

\section{Production and purification of recombinant D-AAO}

After the high cell density fermentation, $1.9 \mathrm{~kg}$ of cells (wet weight) that had an activity of $1,200 \mathrm{U} \mathrm{g} \mathrm{cells}^{-1}$ (wet weight) was harvested. The specific activity in the crude extract was $15 \mathrm{U} \mathrm{mg}$ protein ${ }^{-1}$. We obtained $2.29 \times 10^{6} \mathrm{U}$ of $\mathrm{D}-\mathrm{AAO}$ from one 15-1 fermentation.

The recombinant D-AAO was isolated to homogeneity using a two-step procedure (Table 1). The specific activity of $30 \mathrm{U} \mathrm{mg}$ protein $^{-1}$ in the crude extract could be increased sixfold to $180 \mathrm{U} \mathrm{mg}$ protein ${ }^{-1}$ after the second chromatography. We obtained 1,434 U of D-AAO from $3 \mathrm{~g}$ of cells (wet weight) that corresponded to a yield of $56 \%$. The purification process was monitored by polyacrylamide gel electrophoresis (Fig. 2).

Structural and biochemical characterization

The D-AAO had a native molecular mass of $69 \mathrm{kDa}$ as measured by gel filtration. In combination with the 
Table 1 Purification scheme of D-AAO from the recombinant E. coli BL21(DE3)/pE1D (3 g cells, wet weight)

Total Total Volume Specific Purification Yield activity protein (ml) activity (-fold) (U) $\quad(\mathrm{mg})$ (U $\mathrm{mg}^{-1}$ )

\begin{tabular}{lllllll}
\hline Crude extract & 2,556 & 85 & 10 & 30 & 1.0 & 100 \\
Q-Sepharose & 1,909 & 24 & 9.7 & 80 & 2.7 & 75 \\
Hydroxy-apatite & 1,434 & 8 & 12 & 180 & 6.0 & 56 \\
\hline
\end{tabular}

experimentally and theoretically determined molecular mass of the monomer, this result clearly indicated that the enzyme formed a homodimer. The isoelectric point was 4.4 as determined by isoelectric focussing.

The D-AAO showed activity mainly against basic and hydrophobic D-amino acids (Table 2). Small uncharged and acidic D-amino acids as well as cephalosporin $\mathrm{C}$ were not, or only weakly, oxidized. The enzyme exhibited an absolute stereoselectivity for the tested D-enantiomers. The $K_{\mathrm{m}}$ for D-methionine was $1.0 \pm 0.1 \mathrm{mM}$, whereas L-methionine was a weak, noncompetitive inhibitor for the D-AAO $\left(K_{\mathrm{i}}=315 \pm 39 \mathrm{mM}\right)$ when D-methionine was used as sub-

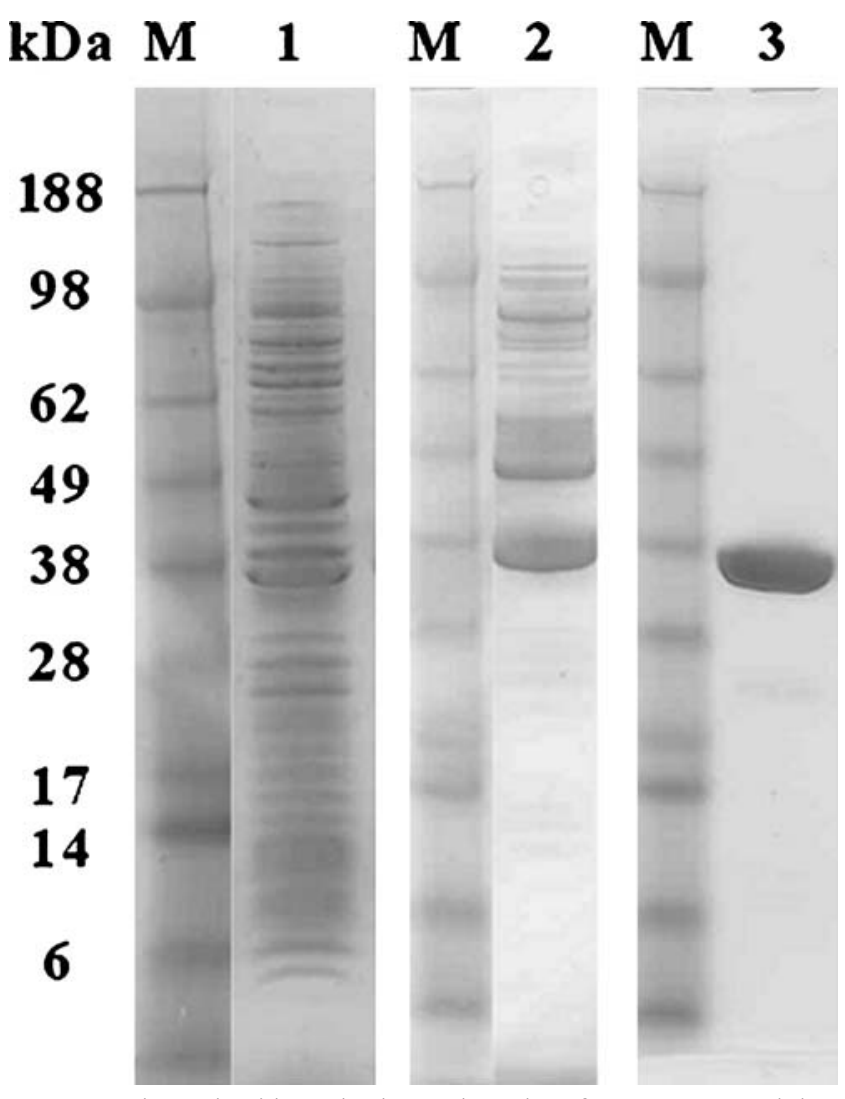

Fig. 2 Polyacrylamide gel electrophoresis of D-AAO containing samples at different stages of purification from E. coli BL21(DE3)/ pE1D, corresponding to Table 1 . Lane $M$ marker; lane 1 crude cell extract; lane 2 pool after anion exchange chromatography; lane 3 pool after hydroxyapatite chromatography
Table 2 Substrate preferences of the recombinant D-AAO

\begin{tabular}{ll}
\hline Substrate & Relative activity (\%) \\
\hline D-Methionine & 100 \\
D-Lysine & 99 \\
4-Fluoro-DL-phenylalanine & 81 \\
D-Arginine & 80 \\
D-Phenylalanine & 54 \\
DL-Homophenylalanine $^{\text {a }}$ & 31 \\
D-Ornithine & 15 \\
D-Leucine & 12 \\
D-Histidine & 5.9 \\
D-Tyrosine & 4.7 \\
$N$-Methyl-DL-leucine & 2.1 \\
D-allo-Isoleucine & 1.0 \\
D-Valine & 0.35 \\
O-Methyl-DL-serine & 0.33 \\
D-Alanine & 0.26 \\
D-Proline & 0.25 \\
DL-tert.-Leucine & 0.12 \\
D-Serine & - \\
D-Asparagine & - \\
D-Aspartic acid & - \\
D-Glutamic acid & - \\
D-Threonine & - \\
D-Tryptophane & - \\
Glycine & - \\
Cephalosporin C & - \\
&
\end{tabular}

The activities were measured at a final substrate concentration of $10 \mathrm{mM}$. In case DL-amino acids were used, the concentration was increased to $20 \mathrm{mM}$

strate. No further L-amino acids were tested as inhibitors. The purified enzyme had a specific activity of $180 \mathrm{U} \mathrm{mg}$ protein $^{-1}$ for D-methionine. The D-AAO had a $\mathrm{pH}$ optimum between 6.5 and 8.5 , and it was stable at $\mathrm{pH}$ values between 6 and 9. The enzyme did not loose activity at temperatures up to $30^{\circ} \mathrm{C}$ for at least $2 \mathrm{~h}$; it had a half life of $21 \mathrm{~min}$ at $40^{\circ} \mathrm{C}$ and of $2 \mathrm{~min}$ at $50^{\circ} \mathrm{C}$ when it was incubated in $100 \mathrm{mM}$ TEA-HCl buffer (pH 7.6).

\section{Discussion}

The D-AAO from A. protophormiae is, to our knowledge, the first characterized enzyme of this class that originates from a bacterial source. The discovery of this prokaryotic D-AAO was facilitated by screening microbial isolates from soil applying a coupled $o$-dianisidine/peroxidase assay. The high stability and sensibility of oxidized $o$-dianisidine (Gabler et al. 2000) allowed the detection of very low enzyme amounts in the crude extract of $A$. protophormiae. One reason for the, hitherto, lack of information on prokaryotic D-AAOs might be the low expression rate in the wild-type strains as we observed in this study. A 
comparison of the specific D-AAO activities in the crude extract of $A$. protophormiae $\left(0.003 \mathrm{U} \mathrm{mg}\right.$ protein $\left.{ }^{-1}\right)$ with recombinant cells (15-30 $\mathrm{U} \mathrm{mg}_{\mathrm{mg}}$ protein ${ }^{-1}$ ) showed that the enzyme was expressed at extremely low amounts in the wild type. The expression rates of the fungal D-AAOproducing strains $R$. gracilis and T. variabilis were $0.6 \mathrm{U}$ mg protein ${ }^{-1}$ (Pilone et al. 1989b) and up to $233 \mathrm{U}$ g cell dry weight $^{-1}$ (Gabler and Fischer 1999; Hörner et al. 1996; Umhau et al. 2000), respectively. These D-AAO activities were induced in the presence of $N$-carbamoyl-D-alanine, Dalanine or D-3-aminobutyric acid.

After the high cell density fermentation of $E$. coli BL21 (DE3)/pE1D, we obtained 153,000 U 1 fermentation broth $^{-1}$. This value is at least 20 -fold higher than all activities that were published for the expression of recombinant and wild-type D-AAOs (Yu et al. 2002; Zheng et al. 2006). Also the specific activity in the crude extracts of recombinant cells (15-30 $\mathrm{U} \mathrm{mg} \mathrm{protein}^{-1}$ ) exceeds the published data for yeast D-AAOs by factors between 3.4 and 60 (Yu et al. 2002; Zheng et al. 2006).

Addition of FAD to the crude extract of E. coli BL21 (DE3)/pE1D and to the purified D-AAO did not increase the activity of the enzyme, indicating that it might be completely expressed as holoenzyme with a very low dissociation constant of FAD. It is also conceivable that it was partially expressed as apoenzyme, but could not bind the added FAD. This behavior differs from other D-AAOs that were expressed in E. coli. Up to $62 \%$ of the $R$. gracilisD-AAO were expressed as apoenzyme in E. coli (Alonso et al. 1998), and the activity of recombinant $T$. variabilis D-AAO could be increased by $33 \%$ when FAD was added to the enzyme assay (Lin et al. 2000).

Under the specified conditions, purified D-AAO from $A$. protophormiae exhibits a specific activity of $180 \mathrm{U} \mathrm{mg}$ protein $^{-1}$ for D-methionine. Comparing the activities of DAAOs from different sources shows that the bacterial enzyme belongs to the highly active D-AAOs. The $T$. variabilis D-AAO had a specific activity of $86 \mathrm{U} \mathrm{mg}$ protein $^{-1}$ for D-alanine $\left(30^{\circ} \mathrm{C}, 50 \mathrm{mM}\right.$ sodium pyrophosphate, $\mathrm{pH}$ 8.5; Pollegioni et al. 1993). Depending on the purification scheme, the $R$. gracilisD-AAO reached specific activities of 58-175 $\mathrm{U} \mathrm{mg}$ protein ${ }^{-1}$ for D-alanine, when the activity was measured at $37^{\circ} \mathrm{C}$ in $75 \mathrm{mM}$ sodium pyrophosphate, $\mathrm{pH} 8.5$ (Pilone et al. 1989a; Pilone et al. 1987). The D-AAOs from the yeasts $T$. variabilis, $R$. gracilis and $C$. boidinii, as well as the fungal and mammalian enzymes from Fusarium oxysporum and pig kidney, respectively, also oxidize D-methionine with high activities.

The purified recombinant D-AAO has a dimeric structure like the enzymes from the well-known yeast strains and an isoelectric point of 4.4 , which is lower than the pIs measured for the D-AAOs from $R$. gracilis (7.8/7.4/7.2), porcine kidney (7.0/7.2) and T. variabilis (5.1) (Pilone et al. 1989a; Pollegioni et al. 1993). The A. protophormiae DAAO has high sequence similarities to putative D-AAOs from different sources and two mammalian D-AspOs (Fig. 1). Several conserved stretches were identified according to Faotto et al. (1995) (Fig. 1). Regions I and III are part of the coenzyme binding site; regions II, IV and V contain residues that are involved in substrate binding and form the active site. The published primary structures of eukaryotic D-AAOs and D-AspO contain a C-terminal signal sequence (SKL) that directs the protein to the peroxisomes (organelles that contain enzymes mainly catalyzing oxidative reactions) and is missing in the shown prokaryotic sequences. The localization of mammalian and yeast D-AAOs in the peroxisomes was proven for several species.

The results described here show that the spectrum of biotechnologically useful D-AAOs was broadened by this highly active and biochemically interesting enzyme from $A$. protophormiae.

Acknowledgment This project was financially supported by the Degussa $A G$ and the Deutsche Bundesstiftung Umwelt (Förderschwerpunkt Biotechnologie, ICBio, Az 13094). We thank Truc Pham for technical assistance and Holger Gieren for expert help with the fermentation.

\section{References}

Alonso J, Barredo JL, Diez B, Mellado E, Salto F, Garcia JL, Cortes E (1998) D-amino-acid oxidase gene from Rhodotorula gracilis (Rhodosporidium toruloides) ATCC 26217. Microbiology 144:1095-1101

Beard TM, Turner NJ (2002) Deracemization and stereoinversion of $\alpha$-amino acids using D-amino acid oxidase and hydride reducing agents. Chem Commun 3:246-247

Berg CP, Rodden FA (1976) Purification of D-amino oxidase from Trigonopsis variabilis. Anal Biochem 71:214-222

Boselli A, Piubelli L, Molla G, Sacchi S, Pilone MS, Ghisla S, Pollegioni L (2004) On the mechanism of Rhodotorula gracilis D-amino acid oxidase: role of the active site serine 335. Biochim Biophys Actia 1702:19-32

Caldinelli L, Molla G, Pilone MS, Pollegioni L (2006) Tryptophan 243 affects interprotein contacts, cofactor binding and stability in D-amino acid oxidase from Rhodotorula gracilis. FEBS J 273:504-512

Casalin P, Pollegioni L, Curti B, Pilone Simonetta M (1991) A study on apoenzyme from Rhodotorula gracilisD-amino acid oxidase. Eur J Biochem 197:513-517

Curti B, Ronchi S, Branzoli U, Ferri G, Williams CH (1973) Improved purification, amino acid analysis and molecular weight of homogenous D-amino acid oxidase from pig kidney. Biochim Biophys Acta 327:266-273

Faotto L, Pollegioni L, Ceciliani F, Ronchi S, Pilone MS (1995) The primary structure of D-amino acid oxidase from Rhodotorula gracilis. Biotechnol Lett 17:193-198

Fukui K, Watanabe F, Shibata T, Miyake Y (1987) Molecular cloning and sequence analysis of cDNAs encoding porcine kidney Damino acid oxidase. Biochemistry 26:3612-3618

Gabler M, Fischer L (1999) Production of a new D-amino acid oxidase from the fungus Fusarium oxysporum. Appl Environ Microbiol 65:3750-3753 
Gabler M, Hensel M, Fischer L (2000) Detection and substrate selectivity of new microbial D-amino acid oxidases. Enzyme Microb Technol 27:605-611

Geueke B, Hummel W (2002) A new bacterial L-amino acid oxidase with a broad substrate specificity: purification and characterization. Enzyme Microb Technol 31:77-87

Gonzalez FJ, Montes J, Martin F, Lopez MC, Ferminam E, Catalan J, Galan MA, Dominguez A (1997) Molecular cloning of TvDAO1, a gene encoding a D-amino acid oxidase from Trigonopsis variabilis and its expression in Saccharomyces cerevisiae and Kluyveromyces lactis. Yeast 13:1399-1408

Goodfellow M, Minnikin DE (1981) The genera Nocardia and Rhodococcus. In: Starr MP, Stolp H, Trüper HG, Balows A, Schlegel HG (eds) The prokaryotes, 1st edn. Springer, Berlin Heidelberg New York, pp 2016-2027

Harris CM, Molla G, Pilone MS, Pollegioni L (1999) Studies on the reaction mechanism of Rhodotorula gracilisD-amino-acid oxidase. Role of the highly conserved Tyr-223 on substrate binding and catalysis. J Biol Chem 274:36233-36240

Hörner R, Wagner F, Fischer L (1996) Induction of the D-amino acid oxidase from Trigonopsis variabilis. Appl Environ Microbiol 62:2106-2110

Isoai A, Kimura H, Reichert A, Schorgendorfer K, Nikaido K, Tohda H, Giga-Hama Y, Mutoh N, Kumagai H (2002) Production of Damino acid oxidase (DAO) of Trigonopsis variabilis in Schizosaccharomyces pombe and the characterization of biocatalysts prepared with recombinant cells. Biotechnol Bioeng 80:22-32

Ju SS, Lin LL, Chien HR, Hsu WH (2000) Substitution of the critical methionine residues in Trigonopsis variabilis D-amino acid oxidase with leucine enhances its resistance to hydrogen peroxide. FEMS Microbiol Lett 186:215-219

Konno R, Yasumura Y (1992) D-amino-acid oxidase and its physiological function. Int J Biochem 24:519-524

Korz DJ, Rinas U, Hellmuth K, Sanders EA, Deckwer WD (1995) Simple fed-batch technique for high cell density cultivation of Escherichia coli. J Biotechnol 39:59-65

Krebs HA (1935) Metabolism of amino acids. Deamination of amino acids. Biochem J 29:77-93

Lin LL, Chien HR, Wang WC, Hwang TS, Fu HM, Hsu WH (2000) Expression of Trigonopsis variabilis D-amino acid oxidase gene in Escherichia coli and characterization of its inactive mutants. Enzyme Microb Technol 27:482-491

Mattevi A, Vanoni MA, Todone F, Rizzi M, Teplyakov A, Coda A, Bolognesi M, Curti B (1996) Crystal structure of D-amino acid oxidase: a case of active site mirror-image convergent evolution with flavocytochrome $b 2$. Proc Natl Acad Sci USA 93:7496-7501

Miura R, Setoyama C, Nishina Y, Shiga K, Mizutani H, Miyahara I, Hirotsu K (1997) Structural and mechanistic studies on D-amino acid oxidase $\times$ substrate complex: implications of the crystal structure of enzyme $\times$ substrate analog complex. J Biochem (Tokyo) 122:825-833

Molla G, Vegezzi C, Pilone MS, Pollegioni L (1998) Overexpression in Escherichia coli of a recombinant chimeric Rhodotorula gracilis D-amino acid oxidase. Protein Expr Purif 14:289-294

Mothet JP, Parent AT, Wolosker H, Brady Jr RO, Linden DJ, Ferris CD, Rogawski MA, Snyder SH (2000) D-Serine is an endogenous ligand for the glycine site of the $N$-methyl-D-aspartate receptor. Proc Natl Acad Sci USA 97:4926-4931
Negri A, Massey V, Williams CH Jr (1987) D-aspartate oxidase from beef kidney. Purification and properties. J Biol Chem 262:10026-10034

Pilone MS, Pollegioni L (2002) D-Amino acid oxidase as an industrial biocatalyst. Biocatal Biotransform 20:145-159

Pilone SM, Vanoni A, Casalin P (1987) Purification and properties of D-amino acid oxidase, an inducible flavoenzyme from Rhodotorula gracilis. Biochim Biophys Acta 914:136-142

Pilone SM, Pollegioni L, Casalin P, Curti B, Ronchi S (1989a) Properties of D-amino-acid oxidase from Rhodotorula gracilis. Eur J Biochem 180:199-204

Pilone SM, Verga R, Fretta A, Hanozet GH (1989b) Induction of Damino acid oxidase by D-alanine in Rhodotorula gracilis grown in defined medium. J Gen Microbiol 135:593-600

Piubelli L, Caldinelli L, Molla G, Pilone MS, Pollegioni L (2002) Conversion of the dimeric D-amino acid oxidase from Rhodotorula gracilis to a monomeric form. A rational mutagenesis approach. FEBS Lett 526:43-48

Pollegioni L, Buto S, Tischer W, Ghisla S, Pilone MS (1993) Characterization of D-amino acid oxidase from Trigonopsis variabilis. Biochem Mol Biol Int 31:709-717

Pollegioni L, Caldinelli L, Molla G, Sacchi S, Pilone MS (2004) Catalytic properties of D-amino acid oxidase in cephalosporin C bioconversion: a comparison between proteins from different sources. Biotechnol Prog 20:467-473

Ramon F, Castillon M, De La Mata I, Acebal C (1998) Chemical mechanism of D-amino acid oxidase from Rhodotorula gracilis: $\mathrm{pH}$ dependence of kinetic parameters. Biochem J 330:311314

Sacchi S, Lorenzi S, Molla G, Pilone MS, Rossetti C, Pollegioni L (2002) Engineering the substrate specificity of D-amino acid oxidase. J Biol Chem 277:27510-27516

Simonic T, Duga S, Negri A, Tedeschi G, Malcovati M, Tenchini ML, Ronchi S (1997) cDNA cloning and expression of the flavoprotein D-aspartate oxidase from bovine kidney cortex. Biochem J 322:729-735

Szwajcer E, Mosbach K (1985) Isolation and partial characterization of a D-amino acid oxidase against cephalosporin $\mathrm{C}$ from the yeast Trigonopsis variabilis. Biotechnol Lett 7:1-7

Tishkov VI, Khoronenkova SV (2005) D-Amino acid oxidase: structure, catalytic mechanism, and practical application. Biochemistry (Mosc) 70:40-54

Umhau S, Pollegioni L, Molla G, Diederichs K, Welte W, Pilone MS, Ghisla S (2000) The X-ray structure of D-amino acid oxidase at very high resolution identifies the chemical mechanism of flavindependent substrate dehydrogenation. Proc Natl Acad Sci USA 97:12463-12468

Watanabe F, Fukui K, Momoi K, Miyake Y (1989) Expression of normal and abnormal porcine kidney D-amino acid oxidase in Escherichia coli: purification and characterization of the enzymes. Biochem Biophys Res Commun 165:1422-1427

Yu J, Li D-Y, Zhang Y-J, Yang S, Li R, Yuan Z-Y (2002) High expression of Trigonopsis variabilis D-amino acid oxidase in Pichia pastoris. J Mol Catal B Enzym 18:291-297

Zheng H, Wang X, Chen J, Zhu K, Zhao Y, Yang Y, Yang S, Jiang W (2006) Expression, purification, and immobilization of Histagged D-amino acid oxidase of Trigonopsis variabilis in Pichia pastoris. Appl Microbiol Biotechnol 70:683-689 